\title{
Host Range of Cyclospora Species: Zoonotic Implication
}

\author{
Piotr Solarczyk iD https://orcid.org/0000-0002-2862-4742 \\ Department of Biology and Medical Parasitology, Poznan University of Medical Sciences, Poznan, Poland
}

\begin{abstract}
Cyclospora is an intracellular, gastrointestinal parasite found in birds and mammals worldwide. Limited accessibility of the protozoan for experimental use, scarcity, genome heterogeneity of the isolates and narrow panel of molecular markers hamper zoonotic investigations. One of the significant limitation in zoonotic studies is the lack of precise molecular tools that would be useful in linking animal vectors as a source of human infection. Strong and convincing evidence of zoonotic features will be achieved through proper typing of Cyclospora spp. taxonomic units (e.g. species or genotypes) in animal reservoirs. The most promising method that can be employ for zoonotic surveys is next-generation sequencing.
\end{abstract}

Keywords: Cyclospora, animals, zoonosis, epidemiology, genotyping, next-generation sequencing.

\section{INTRODUCTION}

Cyclospora spp. (Apicomplexa: Eimeriidae) are intestinal protozoan parasites of vertebrate and invertebrate animals. Cyclospora cayetanensis is the only species within the genus Cyclospora known to infect humans. Cyclosporiasis is endemic mostly to tropical and subtropical regions and people living or traveling to such regions may be at increased risk for infection (Ortega et al. 1994; Sherchand and Cross 2001). In early reports associated with human diarrhea, C. cayetanensis was characterized as a coccidian-like body, blue-green alga, large Cryptosporidium or small Isospora-like organism. More recently, it was found to be a new-emerg-

\footnotetext{
Address for correspondence: Piotr Solarczyk, Department of Biology and Medical Parasitology, Poznan University of Medical Sciences, 10 Fredry Street, 61-701 Poznan, Poland. Email: psolar@ ump.edu.pl
}

ing pathogen worldwide (Ortega et al. 1994). Unlike typical zoonotic infections, sporadic cases of cyclosporiasis and large outbreaks have been mostly linked to various kinds of contaminated fresh produce (e.g., basil, cilantro, mesclun lettuce, raspberries) as well as contaminated water. This parasite still raises questions regarding host specificity, epidemiology, and transmissions to humans. Besides, little is known about the possible role of animals as potential reservoirs (Marangi et al. 2015). Also, there is not enough information on the infective dose, when sporulation takes place, and how external circumstances affect the persistence of infectious stages in water and soil. Newly published data imply that the Cyclospora heterogeneity level in humans is much more higher than previously expected in various regions (Hofstetter et al. 2019). There are no animal models, or in vitro culture systems to facilitate C. cayetanensis research. Efforts to achieve experimental infection of several animals have been unsuccessful, suggesting host specificity (Eberhard et al. 2000). 
To date, on the basis of morphometric and molecular studies Cyclospora spp. presence has been detected in several animals species, including mammals and birds (Zerpa et al. 1995; García-López et al. 1996; Pérez Cordón et al. 2008; Pérez Cordón et al. 2009). These findings may have been detections of oocysts passing through gastrointestinal tract (Almeria et al. 2019). Some studies suggested that free-living nematodes, insects, or rotifers could play a role in the spread of Cyclospora (Ortega et al. 2010). One of the significant limitations in zoonotic investigations is the lack of precise molecular tools that would be useful in linking animal vectors as a source of infection (Barratt et al. 2019). Unfortunately, genome size and genetic heterogeneity of the C. cayetanensis may also complicate zoonotic surveys (Cinar et al. 2015). The purpose of this review is to elucidate problems of $C$. cayetanensis zoonotic examinations and characterize possible utility of new advanced molecular approaches facilitating such interpretations in future.

\section{C. cayetanensis animal reservoirs and zoonotic sur- veys}

Despite the multitude of publications on C. cayetanensis infection detected in humans and environmental samples worldwide, little is known about the presence of the parasite in animals. The genus Cyclospora comprises 21 species described from distinct hosts such as arthropods, reptiles, insectivores, and rodents and oocysts of these Cyclospora species are morphologically distinct from the smaller Cyclospora oocyst found in species isolated from primates, including humans (Tab.1). The diagnosis of C. cayetanensis in animals is much more problematic than in humans because animals are hosts of many intestinal coccidian species. Moreover, most of the infections by intestinal protozoa are chronic, so the number of excreted oocysts in animals' faces is low. A low number of oocysts in animal fecal samples might results in difficulties such as detailed measurements of oocysts, sporulation study and observation of sporozoites. Thus, morphological studies of this genus may have been inadequate. Eberhard and coworkers (1999) described three Cyclospora species in monkeys based on the microscopic and molecular description. In this study, parasite isolates were morphologically indistinguishable among each other and from C. cayetanensis, so the data of morphological description alone are insufficient to study the source of human infection (Eberhard et al. 1999). Microscopy alone was also done in dogs. It is known, that dogs are the hosts of the other naturally acquired Apicomplexa species like Hammondia heydorni and Neospora caninum. Shedding of unsporulated oocyst of these species may have been mistakenly recognized as $C$. cayetanensis and consequently, domestic animals were taken into consideration as an origin of human cyclosporasis (Yai et al. 1997; Romero et al. 2000). Similar issues may handicap studies of both domestic and wild animals, where it was suggested that animals might be a source of C. cayetanensis infection (Smith et al. 1996; Legesse and Erko 2004). For the same epidemiological reason, reports linking finding oocysts at the same time in the same area should not be used as proof of a zoonotic source (Zerpa et al. 1995). Extensive studies for $C$. cayetanensis were done in domestic animals (pigs, cows, goats, horses, guinea pigs, cats, chickens, ducks, pigeons, and turkeys), wild monkeys as well as dogs in endemic regions of Haiti, Kenya, and Brazil where a high prevalence of $C$. cayetanensis was previously reported in humans. Surprisingly none of the animal species tested were parasitized by Cyclospora sp. and it was demonstrated that animals not participated in cyclosporiasis transmission (Eberhard et al. 1999; Carollo et al. 2001; Eberhard et al. 2001). In other studies, both microscopy and molecular methods were used to describe zoonotic coccidia in Galliformes ground-feeding birds in Mexico and Peru and in wild waterfowl Anseriformes birds from Poland. Only samples from wild Taiga bean goose (Anser fabalis) and Mute swan (Cygnus olor) were subsequently confirmed by nested PCR using fragment of the small-subunit ribosomal RNA concluding that these waterfowls were infected by C. cayetanensis (Zerpa et al. 1995; García-López et al. 1996; Majewska et al. 2001; Pieniazek et al. 2001). Although C. cayetanensis was confirmed by both methods in these birds, it is unknown whether the protozoan can establish infection, or was passing through the gastrointestinal tract using birds as mechanical vectors (Almeria et al. 2019). In order to determine new C. cayetanensis animal reservoirs, a four-year survey was done in Poland (Majewska et al. 2001; Majewska et al. 2004). Over three thousand fecal samples from farmed, domestic, wild, and zoo animals were studied. In the study fresh fecal samples were collected from wild animals belonged to 13 birds (639 fecal samples), 6 insectivores (72 fecal samples) and 11 rodents (255 fecal samples) species. Furthermore, 1731 fecal samples tested in this work were also obtained from domestic sources (horses, cattle, dogs, cats, turkeys, chickens and geese) from different regions and 711 fecal samples 
Table 1. All known Cyclospora species and their host based on morphology

\begin{tabular}{|c|c|c|c|}
\hline Species & Host & $\begin{array}{l}\text { Oocyst morphology } \\
(\mathrm{mm})\end{array}$ & Author \\
\hline & ARTHROPODA & & \\
\hline \multirow[t]{2}{*}{ C. glomericola } & Glomeris sp. & $25-36 \times 9-10$ & Schneider 1881 \\
\hline & REPTILIA & & \\
\hline C. viperae & $\begin{array}{l}\text { Vipera aspis, } \\
\text { Coluber scalaris, } \\
\text { Natrix viperinus, } \\
\text { Coronella austriaca }\end{array}$ & $10.5 \times 7.5$ & Phisalix 1923 \\
\hline C. babaulti & Vipera berus & $17 \times 10$ & Phisalix 1924b \\
\hline C. tropidonoti & $\begin{array}{l}\text { Natrix natrix } \\
\text { N. stolata }\end{array}$ & $17 \times 10$ & Phisalix 1924c \\
\hline C. scinci & Scinus officinalis & $10 \times 7$ & Phisalix 1924d \\
\hline C. zamenis & Coluber viridiflavus viridiflavus & $17 \times 10$ & Phisalix 1924e \\
\hline C. niniae & Ninia sebae sebae & $14.6 \times 12.3$ & Lainson 1965 \\
\hline \multirow[t]{2}{*}{ C. shneideri } & Anilius scytale scytale & $19.8 \times 16.6$ & Lainson 2005 \\
\hline & INSECTIVORA & & \\
\hline \multirow[t]{3}{*}{ C. caryolytica } & Talpa europaea & b.d. & Schaudinn 1902 \\
\hline & T. micrura coreana, & $16-19 \times 13-16$ & \\
\hline & & $15-18 \times 8-10$ & \\
\hline C. talpae & Talpa europaea & $15-18 \times 10-12$ & Pellérdy and Tanyi 1968 \\
\hline C. megacephali & Scalopus aquaticus & $18.5 \times 15.7$ & Ford and Duszyński 1988 \\
\hline C. ashtabulensis & Parascalops breweri & $18.0 \times 14.3$ & Ford and Duszyński 1989 \\
\hline C. parascalopi & Parascalops breweri & $16.5 \times 13.6$ & Ford and Duszyński 1989 \\
\hline C. duszynskii & Scalopus aquaticus & $10-12 \times 9-11$ & McAllister et al. 2018 \\
\hline \multirow[t]{2}{*}{ C. yatesi } & Scalopus aquaticus & $12-18 \times 10-17$ & McAllister et al. 2018 \\
\hline & RODENTIA & & \\
\hline \multirow[t]{2}{*}{ C. angimurinensis } & Chaetodipus hispidus & $21.9 \times 19.3$ & Ford et al. 1990 \\
\hline & PRIMATES & & \\
\hline C. cayetanensis & Homo sapiens & 7.7-9.9 & Ortega et al. 1994 \\
\hline C. cercopitheci & Cercopithecus aethiops & $8 \times 10$ & Eberhard et al. 1999a \\
\hline C. colobi & Colobus guereza & $8 \times 9$ & Eberhard et al. 1999a \\
\hline C. papionis & Papio anubis & $8 \times 10$ & Eberhard et al. 1999a \\
\hline C. macacae & Macaca mulatta & $8 \times 10$ & Li et al. 2015 \\
\hline
\end{tabular}

from 196 species of various mammals, birds and reptiles were collected from animals kept in captivity at the Poznan Zoological Garden. Some questions arose regarding potential $C$. cayetanensis reservoirs in wild insectivores and rodents. Morphological description of the oocysts found in lesser white-toothed shrew (Crocidura suaveolens), common vole (Microtus arvalis) and fat dormouse (Glis glis) suggested the presence of C. cayetanensis, but not other Eimeria parasites specific for these animals. Typical Eimeria for soricid and murid hosts such as, Caryospora sp., E. firestonei, E. milleri, E. leucodontis or E. gliris have different morphology of their excreted oocysts (Majewska et al. 2001; Pieniazek et al. 2001). Additionally, all positive samples from these three widespread mammalian species were confirmed by molecular method. BLAST results of the SSU-rDNA sequences revealed that sequences of the Cyclospora from lesser white-toothed shrew, common vole and fat dormouse were identical with the deposited sequences of the same molecular 
Table 2. Cyclospora cayetanensis identified in primates using molecular markers nPCR - nested PCR; qPCR - quantitive PCR; SSCP single stranded conformation polymorphism

\begin{tabular}{|c|c|c|c|c|}
\hline Host & Molecular method & Targed & Primers & Author \\
\hline $\begin{array}{l}\text { Baboon } \\
\text { (Papio anubis) }\end{array}$ & $\begin{array}{l}\text { nPCR, } \\
\text { sequencing }\end{array}$ & $18 \mathrm{~S}$ rDNA & $\begin{array}{l}\text { CYCF1E } \\
\text { 5'-GGAATTCCTACCCAATGAAAACAGTTT-3' } \\
\text { CYCR2B } \\
\text { 5'-CGGGATCCAGGAGAAGCCAAGGTAGG-3' } \\
\text { CYCF3E } \\
\text { 5'-GGAA TTCCTTCCGCGCTTCGCTGCGT-3' } \\
\text { CYCR4B } \\
\text { 5'-CGGGATCCCGTCTTCAAACCCCCTACTG-3' } \\
\text { 1FPL } \\
\text { 5'-GCGGATCCGCGGCCGCTGGTTGATCCTGCCAG-3'1520RPL } \\
\text { 5'-GCGGATCCGCGGCCGCYGCAGGTTCACCAC-3' }\end{array}$ & Lopez et al. 1996 \\
\hline $\begin{array}{l}\text { Chimpanzee } \\
\text { (Pan troglodytes) }\end{array}$ & qPCR, SSCP & ITS & $\begin{array}{l}\text { CCITS2F } \\
\text { 5'-GCAGTCACAGGAGGCATATATCC-3' } \\
\text { CCITS2R } \\
\text { 5'-ATGAGAGACCTCACAGCCAAAC-3' }\end{array}$ & Marangi et al. 2015 \\
\hline $\begin{array}{l}\text { Cynomolgus monkey } \\
\text { (Macaca fascicularis) }\end{array}$ & $\begin{array}{l}\text { qPCR, sequencing, } \\
\text { SSCP }\end{array}$ & ITS & $\begin{array}{l}\text { CCITS2F } \\
\text { 5'-GCAGTCACAGGAGGCATATATCC-3' } \\
\text { CCITS2R } \\
\text { 5'-ATGAGAGACCTCACAGCCAAAC-3' }\end{array}$ & Marangi et al. 2015 \\
\hline $\begin{array}{l}\text { Rhesus } \\
\text { (Macaca mulatta) }\end{array}$ & $\begin{array}{l}\text { nPCR } \\
\text { Multiplex PCR, } \\
\text { RFLP }\end{array}$ & $18 \mathrm{~S}$ rDNA & $\begin{array}{l}\text { F1E } \\
\text { 5'-TACCCAATGAAAACAGTTT-3', } \\
\text { R2B } \\
\text { 5'-CAGGAGAAGCCAAGGTAGG-3' } \\
\text { F3E } \\
\text { 5'-CCTTCCGCGCTTCGCTGCGT-3' } \\
\text { R4B } \\
\text { 5'-CGTCTTCAAACCCCCTACTG-3' } \\
\text { CRP999 } \\
\text { 5'-CGTCTTCAAACCCCCACTGTCG-3' } \\
\text { CC719 } \\
\text { 5'-GTAGCCTTCCGCGCTTCG-3' } \\
\text { PDCL661 } \\
\text { 5'-CTGTCGTGGTCATCTGT.CCGC-3' } \\
\text { ESSP841 } \\
\text { 5'-GTTCTATTTTGTTGGTTTCAGGACCA-3' }\end{array}$ & Chu et al. 2004 \\
\hline
\end{tabular}

marker of $C$. cayetanensis from human (Pieniazek et al. 2001). Besides distinct oocysts morphology of the animal host specific coccidia and $C$. cayetanensis, additional molecular methods are needed to evaluate zoonotic sources of human cyclosporiasis. Results of a morphological study of feces from several mammalian species including carnivores, Artiodactyla, and nonhuman primates from a zoological garden in Spain demonstrate that it is impossible to determine the species of Cyclospora solely on the basis of their morphology (Pérez Cordón et al. 2008). C. cayetanensis has been detected mostly in primates using two molecular markers (18S rDNA and ITS), emphasizing their role as potent vectors for human cyclosporosis in different parts of the world (Lopez et al. 1999; Chu et al. 2004; Marangi et al. 2015) (Tab. 2).

\section{Drawbacks of Cyclospora molecular diagnostic in animals}

As a result of the limitation of the microscopic assay, molecular-based methods have been developed for the detection of Cyclospora in various type of samples to assess infection risk (Chacín-Bonilla 2008; Kitajima et al. 2014; Lalonde et al. 2016). To establish a reliable zoonotic outcome, microscopic analysis must be supported by molecular results. Because the pathogen is usually present in very low numbers in fecal samples, the detection is a very challenging task. In humans, molecular assays for Cyclospora detection are primarily dependent on the quality and purity of the genetic material, so a priori choice of DNA extraction method to isolate parasite genetic material from animals is a cru- 
cial step as well (da Silva et al. 1999; Qvarnstrom et al. 2015; Paulos et al. 2016; Qvarnstrom et al. 2018). To date, the data of differences in usability of commercially available DNA extraction kits in animals fecal samples is restricted. To overcome current molecular genotyping problems, three genetic loci such a region within the small subunit ribosomal RNA gene (SSU rRNA), the 70 kilodalton heat shock protein (HSP70) gene, and the ribosomal internal transcribed spacer (ITS) (Sulaiman et al. 2013; Olivier et al. 2001) were primarily developed to improved detection $C$. cayetanensis DNA in human fecal samples. According to the literature, SSU-rDNA and ITS gene fragments were used for Cyclospora typing in animals (Relman et al. 1996; 30 Zhao et al. 2013). However, some caution should be required as the $C$. cayetanensis populations may be heterogeneous. The pathogen is a sexually reproducing organism and any isolate may have genetically heterogeneous sequences. Through this process, sporozoites in a single sporocyst are thought to be genetically identical, while the sporocysts in a single oocyst can be genetically distinct (Shirley et al. 1996; Mzilahowa et al. 2007). Therefore, one Cyclospora oocyst is heterozygous, possessing up to two alleles for any given marker and amplicons may vary in their sequences. New genotyping information for $C$. cayetanensis, derived from mitochondrial genome markers, should be helpful in animal source tracking studies. Next-Generation Sequencing (NGS) is the best technique for such studies (Nascimento et al. 2019; Houghton et al. 2020, Cinar et al. 2020).

\section{NGS shotgun, metabarcoding and commercially available diagnostic test}

Progress on the improvement of emerging molecular tools to Cyclospora DNA detection has been observed but it is mostly fronted for humans (Qvarnstrom et al. 2018). Recent advances in modern sequencing technologies and availability of efficient software led to complete $C$. cayetanensis mitochondrial and apicoplast genomes (Cinar et al. 2015, Cinar et al. 2016, Ogedengbe et al. 2015; Cama and Ortega 2018). The new NGS strategy used on deep sequencing platforms gains from the increasing availability, speed, and decreasing costs. In general, it is based on two approaches. The first is shotgun metagenomics, which profiles the entire microbial diversity consisting of both pathogenic and neutral microbiome of the host. This technique demands the knowledge of partial or whole Cyclospora reference genome, which is then compared to the shotgun data following quality processing, curation, and assembly datasets. The shotgun method may be promising to identify and develop novel target loci of $C$. cayetanensis (Qvarnstrom et al. 2015). The whole genome of C. cayetanensis is estimated to be 44 megabase pairs with $\sim 7500$ genes (Liu et al. 2016). Cyclospora mitochondrial genome is $\sim 6200$ base pairs (bp) in length, whereas the circular apicoplast genome is $\sim 34,000 \mathrm{bp}$ and encodes complete machinery for protein synthesis. The second NGS approach is based on metabarcoding of the small ribosomal RNA subunit (18S), which targets predefined domains using specific primers. This NGS system seems to be extremely useful in terms of the development of new Cyclospora diagnostic assays (Qvarnstrom et al. 2015; Nascimento et al. 2016; Liu et al. 2016). Cinar and coworkers described NGS molecular typing of $C$. cayetanensis identifying potential genomic markers such as single nucleotide polymorphisms (SNP) and insertion-deletions that could theoretically be used for Cyclospora detection and pathogen subtyping in clinical samples (Cinar et al. 2020). These promising results were obtained by typing the mitochondrial genome. It was suggested that the diversity of $C$. cayetanensis and could be used to link outbreaks or even single infection cases to a source. Multicopy and linear mitochondrial genomic sequences observed in C. cayetanensis may also be used for the detection and genotyping of other Cyclospora species (Cinar et al. 2015; Qvarnstrom et al. 2018).

The development of rapid diagnostic molecular tests has improved the detection of various protozoan pathogens thanks to higher throughput capacity (Verweij and Verweij 2014). Besides user-friendly software and equipment independence, the ultimate goal of such tests should be better affordability, sensitivity and specificity. Currently, the BioFire FilmArray panel is the only commercially available product capable of detecting $C$. cayetanensis in addition to 22 enteropathogenic agents (including four protozoan species). Buss and coworkers described the sensitivity and specificity of this test during a cyclosporiasis outbreak in the USA (Buss et al. 2013). In another study, over one and half thousand clinical stool samples were analyzed, showing that the sensitivity and specificity of this test for C. cayetanensis was 100\% (Buss et al. 2015; Murphy et al. 2019). Up to now, no reports were published on the use of this commercial test to analyze samples from animals. 


\section{CONCLUSION}

The results of many studies indicated that Cyclospora is a very rare pathogen in animals, so any zoonotic surveys became a very challenging task. To establish a proper outcome, morphometric analysis, together with sporulation test should be use as primary method. Animals can harbor many coccidian (the largest group of apicomplexan protozoa) species and microscopy alone is limited by poor resolution needed for proper Cyclospora classification (Li et al. 2015; Giangaspero and Gasser 2019). To avoid any identification issues of C. cayetanensis in animals, molecular data must support the microscopic results. Several molecular based detection methods along with two molecular markers have been developed to identify $C$. cayetanensis in various animals so far (Lalonde and Gajadhar 2011). The most frequent gene fragments used for Cyclospora identification in animals were the SSU-rDNA and ITS loci. The major drawback comes from the primers used to obtain Cyclospora SSU-rDNA amplicons, because such primers may also cross-amplify other Eimeria DNA in animals. Generally, narrow panel of genetic markers for zoonotic investigations suppress final zoonotic conclusions (Giangaspero and Gasser 2019). While the advances in development of molecular methods have been significant in the last decade, there are no data supporting genetic diversity among Cyclospora isolates in animal hosts, which may reflect the protozoan infectivity and non-zoonotic/zoonotic interactions. However, as a consequence of Cyclospora heterogeneity in the probes, no independently validated genotyping approaches have been developed for zoonotic purposes. The NGS technology may be invaluable for this strategy generating complex data usable for tracing Cyclospora zoonotic sources of human infection. NGS shotgun or metabarcoding of nuclear and mitochondrial data for comparative genomic analyses will become an important approach for unculturable C. cayetanensis in future, but the genome size is a hindrance to routine use in whole genome sequencing (Guo et al. 2019). Strong and convincing evidence of Cyclospora zoonotic features will be achieved through proper typing of Cyclospora spp. taxonomic units (e.g. species or genotypes) in animal reservoirs (Tang et al. 2015). Also assessment is needed whether the parasite is able to establish infection by examination of tissue biopsies as well as estimation of Cyclospora population structure in animals.

\section{REFERENCES}

Almeria S., Cinar H. N., Dubey J. P. (2019) Cyclospora cayetanensis and Cyclosporiasis: An Update. Microorganisms. 7: 317

Barratt J. L. N., Park S., Nascimento F. S., Hofstetter J., Plucinski M., Casillas S., Bradbury R. S., Arrowood M. J., Qvarnstrom Y., Talundzic E. (2019) Genotyping genetically heterogeneous Cyclospora cayetanensis infections to complement epidemiological case linkage. Parasitology. 146: 1275-1283

Buss S. N., Alter R., Iwen P. C., Fey P. D. (2013) Implications of culture-independent panel-based detection of Cyclospora cayetanensis. J. Clin. Microbiol. 51: 3909

Buss S. N., Leber A., Chapin K., Fey P. D., Bankowski M. J., Jones M. K., Rogatcheva M., Kanack K. J., Bourzac K. M. (2015) Multicenter evaluation of the BioFire FilmArray Gastrointestinal Panel for etiologic diagnosis of infectious gastroenteritis. J. Clin. Microbiol. 53: 915-925

Cama V. A and Ortega Y. R. (2018) Cyclospora cayetanensis. In Foodborne Parasites, 2nd ed.; Ortega Y. R., Sterling C. R., Eds.; Springer: Berlin/Heidelberg, Germany, 2018; pp. 41-56

Carollo M. C., Amato Neto V., Braz L. M. A., Kim D. W. (2001) Detection of Cyclospora sp. oocysts in the feces of stray dogs in Greater Sao Paulo (Sao Paulo State, Brazil). Rev. Soc. Bras. Med. Trop. 34: 597-598

Chacín-Bonilla L. (2008) Transmission of Cyclospora cayetanensis infection: A review focusing on soil-borne cyclosporiasis. Trans. R. Soc. Trop. Med. Hyg. 102: 215-216

Chu D. M. T., Sherchand J. B., Cross J. H., Orlandi P. A. (2004) Detection of Cyclospora cayetanensis in animal fecal isolates from Nepal using an FTA filter-base polymerase chain reaction method. Am. J. Trop. Med. Hyg. 71: 373-379

Cinar H. N., Gopinath G., Jarvis K., Murphy H. R. (2015) The complete mitochondrial genome of the foodborne parasitic pathogen Cyclospora cayetanensis. PLOS ONE 10, e0128645

Cinar H. N., Gopinath G., Murphy H. R., Almeria S., Durigan M., Choi D., Jang A., Kim E., Kim R., Choi S., Lee J., Shin Y., Lee J., Qvarnstrom Y., Benedict T. K., Bishop H. S., da Silva A. (2020) Molecular typing of Cyclospora cayetanensis in produce and clinical samples using targeted enrichment of complete mitochondrial genomes and next-generation sequencing. Parasit Vectors. 13: 122

da Silva A. J., Bornay-Llinares F. J., Moura I. N., Slemenda S. B., Tuttle J. L., Pieniazek N. J. (1999) Fast and reliable extraction of protozoan parasite DNA from fecal specimens. Mol. Diagn. 4: $57-64$

Eberhard M. L., da Silva A. J., Lilley B. G., Pieniazek N. J. (1999a) Morphologic and molecular characterization of new Cyclospora species from Ethiopian monkeys: C. cercopitheci sp. n., C. colobi sp. n., C. papionis sp. n. Emerg. Infect. Dis. 5: 651658

Eberhard M. L., Nace E. K., Freeman A.R. (1999) Survey for $C y$ clospora cayetanensis in domestic animals in an endemic area in Haiti. J. Parasitol. 85: 562-563

Eberhard M. L., Njenga M. N., da Silva A. J., Owino D., Nace E. K., Won K. Y., Mwenda J. M. (2001) A survey for Cyclospora spp. in Kenyan primates, with some notes on its biology. J. Parasitol. 87: 1394-1397

Eberhard M. L., Ortega Y. R., Hanes D. E., Nace E. K., Do R. Q., Robl M. G., Won K. Y., Gavidia C., Sass N. L., Mansfield K. (2000) Attempts to establish experimental Cyclospora cayetanensis infection in laboratory animals. J. Parasitol. 86: 577-582 
Ford P. L., Duszynski D. W. (1988) Coccidian parasites (Apicomplexa: Eimeriidae) from insectivores. VI. Six new species from eastern mole, Scalopus aquaticus. J. Protozool. 35: 223-226

Ford P. L., Duszynski D. W. (1989) Coccidian parasites (Apicomplexa: Eimeriidae) from insectivores. VII. Six new species from the hairy-tailed mole, Parascalops breweri. J. Parasitol. 75: 508-513

Ford P. L., Duszynski D. W., McAllister C. T. (1990) Coccidia (Apicomplexa) from heteromyid rodents in the southwestern United States, Baja California, and northern Mexico with three new species from Chaetodipus hispidus. J. Parasitol. 76: 325-331

García-López H. L., Rodríguez-Tovar L. E., Medina-De la Garza C. E. (1996) Identification of Cyclospora in poultry. Emerg. Infect. Dis. 2: 356-357

Giangaspero A., Gasser R. B. (2019) Human cyclosporiasis. Lancet Infect. Dis. 19:e226-e236

Guo Y., Wang Y., Wang X., Zhang L., Ortega Y., Feng Y. (2019) Mitochondrial genome sequence variation as a useful marker for assessing genetic heterogeneity among Cyclospora cayetanensis isolates and source-tracking. Parasit. Vectors. 12: 47

Hofstetter J. N., Nascimento F. S., Park S., Casillas S., Herwaldt B. L., Arrowood M. J., Qvarnstrom Y. (2019) Evaluation of multilocus sequence typing of Cyclospora cayetanensis based on microsatellite markers. Parasite. 26: 3

Houghton K. A., Lomsadze A., Park S., Nascimento F. S., Barrat J., Arrowood M. J., VanRoey E., Talundzic E., Borodovsky M., Qwarnstrom Y. (2020) Development of a workflow for identification of nuclear genotyping markers for Cyclospora cayetanensis. Parasite. 27: 24

Kitajima M., Haramoto E., Iker B. C., Gerba C. P. (2014) Occurrence of Cryptosporidium, Giardia, and Cyclospora in influent and effluent water at wastewater treatment plants in Arizona. Sci. Total Environ. 484: 129-136

Lainson R. (1965) Parasitological studies in British Honduras. II. Cyclospora niniae sp. nov. (Eimeriidae, Cyclosporinae) from the snake Ninia sebae sebae (Colubridae). Ann. Trop. Med. Parasitol. 59: 159-163

Lainson R. (2005) The Genus Cyclospora (Apicomplexa: Eimeriidae), with a description of Cyclospora schneideri n.sp. in the snake Anilius scytale scytale (Aniliidae) from Amazonian Brazil - a review. Mem. Inst. Oswaldo Cruz. 100: 103-110

Lalonde L. F. and Gajadhar A. A. (2011) Detection and differentiation of coccidian oocysts by real-time PCR and melting curve analysis. J. Parasitol. 97: 725-730

Lalonde L. F. and Gajadhar A. A. (2016) Detection of Cyclospora cayetanensis, Cryptosporidium spp., and Toxoplasma gondii on imported leafy green vegetables in Canadian survey. Food $\mathrm{Wa}$ terborne Parasitol. 2: 8-14

Legesse M., Erko B. (2004) Zoonotic intestinal parasites in Papio anubis (baboon) and Cercopithecus aethiops (vervet) from four localities in Ethiopia. Acta Trop. 90: 231-236

Li N., Ye J., Arrowood M. J., Ma J., Wang L., Xu H., Feng Y., Xiao L. (2015) Identification and morphologic and molecular characterization of Cyclospora macacae n. sp. from rhesus monkeys in China. Parasitol. Res. 114: 1811-1816

Liu S., Wang L., Zheng H., Xu Z., Roellig D. M., Li N., Frace M. A., Tang K., Arrowood M. J., Moss D. M., et al. (2016) Comparative genomics reveals Cyclospora cayetanensis possesses coccidia-like metabolism and invasion components but unique surface antigens. BMC Genom. 17: 316

Lopez F. A., Manglicmot J., Schmidt T. M., Yeh C., Smith H. V., Relman D. A. (1996) Molecular characterization of Cyclosporalike organisms from baboons. J. Infect. Dis. 179: 670-676
Majewska A. C. (2004) Zwierzęce rezerwuary Cyclospora spp. i specyficzność żywicielska, in: Majewska A. C., Nowosad P. (Eds), Cyclospora spp. enigmatyczne pasożyty wewnątrzkomórkowe. Wydawnictwo Naukowe Akademii Medycznej im. Karola Marcinkowskiego w Poznaniu, 24-39

Majewska A. C., Werner A., Słodkowicz A., Piłacińska B. (2001) Występowanie pasożytniczych pierwotniaków jelitowych $\mathrm{u}$ dzikich gryzoni i owadożernych odłowionych w rejonie Wielkopolski. Wiad. Parazytol. 47: 29

Majewska A. C., Kosiński Z., Werner A., Sulima P., Nowosad P. (2001) Pasożytnicze pierwotniaki jelitowe: nowe wodnopochodne zagrożenie zdrowia publicznego. Wydawnictwo Uczelniane Akademii Medycznej im. Karola Marcinkowskiego w Poznaniu, 26

Marangi M., Koehler A. V., Zanzani S. A., Manfredi M. T., Brianti E., Giangaspero A., Gasser R. B. (2015) Detection of Cyclospora in captive chimpanzees and macaques by a quantitative PCR-based mutation scanning approach. Parasites Vectors. 8: 274 doi: 10.1186/s13071-015-0872-8

McAllister C. T., Motriuk-Smith D., Kerr C. M. (2018) Three new coccidians (Cyclospora, Eimeria) from eastern moles, Scalopus aquaticus (Mammalia: Soricomorpha: Talpidae) from Arkansas, USA. Syst Parasitol. 95: 271-279

Murphy H. R., Lee S., da Silva A. J. (2017) Evaluation of an improved U.S. Food and Drug Administration method for the detection of Cyclospora cayetanensis in produce using real-time PCR. J. Food Prot. 80: 1133-1144

Mzilahowa T., McCall P. J., Hastings I. M. (2007) 'Sexual' population structure and genetics of the malaria agent $P$. falciparum. PLoS ONE 2: e613

Nascimento F. S, Wei-Pridgeon Y., Arrowood M. J., Moss D., da Silva A. J., Talundzic E., Qvarnstrom Y. (2016) Evaluation of library preparation methods for Illumina next generation sequencing of small amounts of DNA from foodborne parasites. J. Microbiol. Methods. 130: 23-26

Nascimento F. S., Barta J. R., Wale J., Hofstetter J. N., Casillas S., Barratt J., Talundzic E., Arrowood M. J., Qvarnstrom Y. (2019) Mitochondrial junction region as genotyping marker for Cyclospora cayetanensis. Emerg. Infect. Dis. 25: 1307-1312

Ogedengbe M. E., Qvarnstrom Y., da Silva A. J., Arrowood M. J., Barta J. R. (2015) A linear mitochondrial genome of Cyclospora cayetanensis (Eimeriidae, Eucoccidiorida, Coccidiasina, Apicomplexa) suggests the ancestral start position within mitochondrial genomes of eimeriid coccidia. Int. J. Parasitol. 45: $361-365$

Olivier C., van de Pas S., Lepp P. W., Yoder K., Relman D. A. (2001) Sequence variability in the first internal transcribed spacer region within and among Cyclospora species is consistent with polyparasitism. Int. J. Parasitol. 31: 1475-1487

Ortega Y. R. and Sanchez R. (2010) Update on Cyclospora cayetanensis, a food-borne and waterborne parasite. Clin. Microbiol. Rev. 23: 218-234

Ortega Y. R., Gilman R. H., Sterling C. R. (1994) A new coccidian parasite (Apicomplexa: Eimeriidae) from humans. J. Parasitol. 80: $625-629$

Paulos S., Mateo M., de Lucio A., Hernández-de Mingo M., Begoña Bailo B., Saugar J. M., Cardona G. A., Fuentes I., Mateo M., Carmena D. (2016) Evaluation of five commercial methods for the extraction and purification of DNA from human feacal samples for downstream molecular detection of the enteric protozoan parasites Cryptosporidium spp., Giardia duodenalis and Enatamoeba spp. J. Microbiol. Methods. 21: 520-528 
Pellérdy L., Tanyi J. (1968) Cyclospora talpae sp. n. (Protozoa, Sporozoa) from the liver of Talpa europaea. Folia Parasitol. 15: $275-277$

Pérez Cordón G., Hitos Prados A., Romero D., Sánchez Moreno M., Pontes A., Osuna A., Rosales M. J. (2008) Intestinal parasitism in the animals of the zoological garden "Peña Escrita" (Almuñecar, Spain). Vet. Parasitol. 156: 302-309

Pérez Cordón G., Hitos Prados A., Romero D., Sánchez Moreno M., Pontes A., Osuna A., Rosales M. J. (2009) Intestinal and haematic parasitism in the birds of the Almuñecar (Granada, Spain) ornithological garden. Vet. Parasitol. 165: 361-366

Phisalix M. (1923) Coccidiose intestinale de Vipera aspic à Cyclospora viperae n. sp. Bull. Soc. Path. Exot. 16: 637-642

Phisalix M. (1924b). Coccidiose intestinale de Vipera berus à $C y$ clospora babaulti nov. sp. Bull. Soc. Path. Exot. 17: 868-871

Phisalix M. (1924c) Cyclospora tropidonoti nov. spec. coccidie intestinale de la couleuvre à Collier. Bull. Soc. Path. Exot. 17: 871-873

Phisalix M. (1924d) Coccidiose intestinale du Scinus officinalis Laur., à Cyclospora scinici nov. spec. B. Mus. Nat. Hist. Nat. 1: 100-101

Phisalix M. (1924e) Cyclospora zameniss nov. sp., coccidie à localization intestinale de Zemenis viridiflavus Lacép. B. Mus. Nat. Hist. Nat. 6: 501-502

Pieniazek N. J., Moura I. N. S., Majewska A. C., Sulima P., Słodkowicz A., Werner A., Kosiński Z. (2001) Molekularna charakterystyka izolatów Cyclospora ptaków, jaszczurek, owadożernych i gryzoni. Wiad. Parazytol. 47: 37

Qvarnstrom Y., Benedict T., Marcet P. L., Wiegand R. E., Herwaldt B. L., da Silva A. J. (2018) Molecular detection of Cyclospora cayetanensis in human stool specimens using UNEX-based DNA extraction and real-time PCR. Parasitology. 145: 865-870

Qvarnstrom Y., Wei-Pridgeon Y., Li W., Nascimento F. S., Bishop H. S., Herwaldt B. L., Moss D. M., Nayak V., Srinivasamoorthy G., Sheth M. et al. (2015) Draft genome sequences from Cyclospora cayetanensis oocysts purified from a human stool sample. Genome Announc. 3(6):e01324-15

Qvarnstrom Y., Wei-Pridgeon Y., VanRoey E., Park S., Srinivasamoorthy G., Nascimento F. S., Moss D. M., Talundzic E., Arrowood M. J. (2018) Purification of Cyclospora cayetanensis oocysts obtained from human stool specimens for whole genome sequencing. Gut Pathog. 10: 45

Relman D. A., Schmidt T. M., Gajadhar A., Sogin M., Cross J., Yoder K., Sethabutr O., Echeverria P. (1996) Molecular phylogenetic analysis of Cyclospora, the human intestinal pathogen, suggests that it is closely related to Eimeria species. J. Infect. Dis. 173: 440-445
Romero M. Q., Chávez A. V., Casas E. A. (2000) Determinación de la presencia de Cryptosporidium parvum Cyclospora sp. en caninos domésticos (Canis familiaris) en los distritos de Lima metropolitana. Rev. Inv. Vet. Perú. 11: 26-31

Schaudinn F. (1902) Studies über kraknkheitserregende Protozoen. I. Cyclospora caryolytica Schaud., der Erreger der perniciosen Enteritis den Maulwurfs. Arb. Kais. Gesundh. 18

Sherchand J. B., Cross J. H. (2001) Emerging pathogen Cyclospora cayetanensis infection in Nepal. Southeast Asian J. Trop. Med. Public Health, 32: 143-150

Shirley M. W., Harvey D. A. (1996) Eimeria tenella: infection with a single sporocyst gives a clonal population. Parasitology. 112: 523-528

Shneider A. (1881) Sur les psorospermies oviformes ou coccidies. Espèces nouvelles ou peu connues. Arch. Zool. Exp. Gén. 9: 387-404

Smith H. V., Paton C. A., Girdwood R. W. A. Mtambo M. M. A. (1996) Cyclospora in non-human primates. Vet. Rec. 138: 528

Sulaiman I. M., Torres P., Simpson S., Kerdahi K., Ortega Y. (2013) Sequence characterization of heat shock protein gene of $C y$ clospora cayetanensis isolates from Nepal, Mexico, and Peru. J. Parasitol. 99: 379-382

Tang K., Guo Y., Zhang L., Rowe L. A., Roellig D. M., Frace M. A., Li N., Liu S., Feng Y., Xiao L. (2015) Genetic similarities between Cyclospora cayetanensis and cecum-infecting avian Eimeria spp. in apicoplast and mitochondrial genomes. Parasit. Vectors 8: 358

Verweij J. J. and Stensvold R. C. (2014) Molecular testing for clinical diagnosis and epidemiological investigations of intestinal parasitic infections. Clin Microbiol Rev. 27: 371-418

Yai L. E., Bauab A. R., Hirschfeld M. P., de Oliveira M. L., Damaceno J. T. (1997) The first two cases of Cyclospora in dogs, São Paulo, Brazil. Rev. Inst. Med. Trop. São Paulo. 39: 177-179

Zerpa R., Uchima N., Huicho L. (1995) Cyclospora cayetanensis associated with watery diarrhoea in Peruvian patients. Am. J. Trop. Med. Hyg. 98: 325-329

Zhao G. H., Cong M. M. Bian Q. Q., Cheng W. Y., Wang R. J., Qi M., Zhang L. X., Lin Q., Zhu X. Q. (2013) Molecular characterization of Cyclospora-like organisms from golden snub-nosed monkeys in Qinling Mountain in Shaanxi province, northwestern China. PLoS ONE 8: e58216

Received on $10^{\text {th }}$ April, 2021; revised on $17^{\text {th }}$ June, 2021; accepted on $23^{\text {rd }}$ June, 2021 